\title{
IMPACT OF ECONOMIC, FINANCIAL AND POLITICAL RISKS ON TOURISM PERFORMANCE: A CASE OF SOUTH AFRICA
}

\author{
Paul-Francois MUZINDUTSI* \\ University of KwaZulu-Natal, School of economics and Accounting, University Rd, Westville, South Africa, e-mail: MuzindutsiP@ukzn.ac.za \\ Fikile DUBE \\ University of KwaZulu Natal, School of economics and Accounting, University Rd, Westville, South Africa, e-mail: DubeF1@ukzn.ac.za
}

Jean-Claude MANALIYO

North-West University, School of Tourism Management, Albert Luthuli

and University Drive, Mmabatho, South Africa, e-mail: 25842927@nwu.ac.za

\begin{abstract}
Citation: Muzindutsi, P.F., Dube, F., \& Manaliyo, J.C. (2021). IMPACT OF ECONOMIC, FINANCIAL AND POLITICAL RISKS ON TOURISM PERFORMANCE: A CASE OF SOUTH AFRICA. GeoJournal of Tourism and Geosites, 38(4), 13091316. https://doi.org/10.30892/gtg.38439-773
\end{abstract}

\begin{abstract}
The contribution of tourism to a country's economy is determined by country risk measures such as economic, financial and political risk. This study aimed to investigate short and long-run effects of country risk factors on international tourist arrivals and tourism revenue for the South African tourism industry. The sample period consists of monthly time series data of tourist arrivals, tourism revenue, and country risk factors from January 2004 to December 2018. Data was analysed using the Autoregressive distributed lag (ARDL) and non-linear ARDL (NARDL) models. The findings showed that the long-run effects of country risk factors on tourist arrivals and revenue are asymmetric. Economic, financial, and political measures of country risk negatively affect tourist arrivals, however, tourism revenue responds differently to changes in these risk factors. Political risk has the highest effect on the tourism industry compared to economic and financial risk factors. Overall, this study established that both international tourist arrivals and tourism revenue are threatened by financial shocks indicating that an unconducive financial environment has long-term negative implications on the South African tourism industry.
\end{abstract}

Key words: Economic risk, financial risk, political risk, tourism revenue, tourist arrivals, ARDL

\section{INTRODUCTION}

The international tourism industry has shown stable growth in terms of tourist arrivals and tourism receipts after the 2008 economic and financial crisis, which caused a reduction in tourist arrivals and tourism receipts. During 2009 for example, international tourist arrivals worldwide declined to 880 million from 922 million international tourist arrivals that was recorded in 2008 (United Nations World Tourism Organisation [UNWTO], 2010). International tourism receipts contracted by 6\% in 2009 compared with tourism receipts reported in 2008 (UNWTO, 2015). Tourism recovered in 2010 as international tourist arrivals increased by $6.6 \%$ to reach 940 million, and maintained its momentum of growth in both tourist arrivals and receipts since then. International tourist arrivals grew to 1.133 billion and tourism receipts reached US\$1.3 trillion in 2014 (UNWTO, 2015) whereas, in 2019, international tourist arrivals increased to 1.4 billion and tourism receipts increased to US\$ 1.7 trillion respectively (UNWTO, 2019a). International tourist arrivals and tourism receipts however, are disproportionally distributed in countries and regions across the world (World Travel and Tourism [WTTC], 2020). There is evidence that advanced economies maintain a larger share of international tourist arrivals and tourism receipts than developing countries due to various factors, including economic, financial and political risks (UNWTO, 2019b). This study investigated the influence of economic, financial and political risks on tourism, focusing on South Africa. Economic risk is induced by factors such as exchange rate, inflation, contract cancellation, uncertainty of economic development, incoherent laws and regulations, lack of financial resources, rising interest rates and tax (Oláh at al., 2019; Platon et al., 2014). On the other hand, financial risk is heightened by factors such as interest rate risk, exchange rate risk, foreign investment risk, refinancing risk, and currency risk (Fan and Luo, 2018), whereas political risk is linked by factors such as crime, corruption, political unrest, internal and external conflicts, terrorism, instability in governance, and expropriation among other factors (PRS Group, 2018).

The tourism industry is susceptible to economic, financial, and political risks. Literature showed that the prevalence of one or many risks makes countries hostile and unconducive for tourism activities (Basu and Marg, 2013; Çertinsoz and Age, 2013 Kandir et al., 2015; Poprawe, 2015), leading to declining tourist arrivals and tourism receipts. Risk is a key factor tourists consider in their travel plan, especially when selecting destinations (Ferreira et al., 2019; Nugraha et al., 2016), indicating that economic, financial and political risks are determining factors of the arrivals of foreign tourists and tourism receipts in countries. Global international tourism demand, for example, was negatively affected by the 2008 global 
economic crisis (UNWTO and International Labour Organisation [ILO], 2013). Evidence shows that tourism performance in different countries across the world is adversely affected by economic crisis. For example, international tourists to Cuba reduced by $27.8 \%$ in 2019 as a result of economic sanctions imposed by the United States of America against the country (Dolgos, 2019). Contrarily, economic sanctions imposed on Iran attracted many inbound tourists, but the sanctions reduced the number of outbound tourists (Farahani and Shabani, 2014). The presence of one or more economic risk factors in a country inhibit international tourists, resulting in reduced consumption of tourism products and services.

Countries subjected to economic risk are often evaded by or become inaccessible for international tourists. For example, when the United States suspended all the United States airlines, cruise ships, private jets and yachts to Cuba, foreign tourist arrivals to the country declined significantly (Dolgos, 2019). In Zimbabwe, the tourism industry was crippled by the western economic sanctions which eroded the ability of the country to provide appealing infrastructure to tourists. Zimbabwe's infrastructure in different sectors deteriorated due to economic sanctions imposed by the US and other western countries (Thabani, 2019). Tourism infrastructure may be viewed as the backbone of the tourism industry. Poor or lack of tourism infrastructure has a negative impact on tourist arrivals. A study conducted in Mauritius showed that a $10 \%$ increase in stock of infrastructure leads to an increase (3.2\%) in tourist arrivals in the country (Seetanah et al., 2011).

Economic sanctions often cause instability of exchange rates in a sanctioned country. This increases the exchange rate, resulting in the devaluation of a local currency against foreign currencies (Azhar et al., 2018; Dastgerdi et al., 2018). The devaluation of a local currency makes a country affordable to foreign tourists, resulting in increased tourist arrivals. Tourists often react positively to the depreciation of currencies in host countries (Quadri and Zheng, 2011; Tung, 2019; Vojtko et al., 2018). However, the depreciation of a local currency may adversely impact tourism and the economy as a whole due to the fact that it makes imported goods and services expensive, causing inflation (Kandil, 2015).

Brown (2000), Everhart et al., (2003) found that tourism is also threatened by increasing political risk. Tourism, especially international tourism is vulnerable to political risk factors such as conflicts, corruption, crime, political instability and terrorist attacks (Basu and Marg, 2013; Ekine 2018; Yap and Saha, 2013). Within this context, countries perceived to have high political risk experience reduced tourist arrivals and tourism revenue. Politically troubled countries are often avoided by international tourists (Ito and Lee, 2005). Different studies have found that countries with a high perception level of corruption record a low number of tourist arrivals (Ekine, 2018; Poprawe, 2015; Santa-Gallego et al., 2016). This implies that the inflow of tourists increases when the perception of corruption decreases. Poprawe (2015) found that tourist arrivals increase between $2 \%$ and $7 \%$ if corruption perception indexes decline by one point. In certain countries, corruption has no effect or has a positive effect on tourist arrivals. For example, Yap and Saha (2013) found that tourist arrivals in Uganda increased between 1999 and 2009 amid the country's high level of corruption.

Studies indicate that the occurrence of terrorist attacks drives away tourists (Baker, 2014; Basu and Marg, 2013; Santana-Gallego et al., 2016). Tourists avoid countries subject to terror attacks irrespective of whether the attacks target tourist facilities or not. Tourists choose to visit countries perceived to be safe. Resultantly, the countries that experience terrorist attacks experience a low number of tourists. Santana-Gallego et al. (2016) found that tourist arrivals decline by $1.74 \%$ when terror attacks go up by $1 \%$. The inflow of tourists to Egypt and Jordan plummeted in the aftermath of terrorist attacks (Basu and Marg, 2013). After terrorist attacks, potential tourists select to visit other countries perceived as safe, while attacked countries lose tourism revenue (Al-Shorman et al., 2016; Baker, 2014). Certain countries may still attract tourists despite facing terror threats because of the specific tourism products offered by the countries. Terror attacks are unlikely to adversely affect countries that have cultural heritage sites (Santana-Gallego et al., 2016). Political risk linked to political instability was found to have a devastating effect on both tourist arrivals and tourism revenue (Chingarande, 2014; Ingram et al., 2013; Ivanov et al., 2016; Kebede, 2018; Neumayer, 2004). The number of tourists that visited Egypt, for example, fell to 10 million in 2011 from 15 million tourists, which were recorded in 2010 (Chingarande, 2014). Political risk also reduced overnight stays and revenue in Ukraine (Ivanov et al., 2016). The reduction in revenue and tourist arrivals is attributed to tourists' preference to visit politically stable countries over countries in political turmoil. Political instability is not only a threat to tourist inflows and revenue, it also impedes tourism development and operations of tourism businesses.

Tourism in certain country destinations performs poorly due to criminal activities that target tourists. Crime is a serious threat to tourism in both developed and developing countries (Baker and Stockton, 2014; Biagi et al., 2012). Criminals believe that tourists have a lot of money and expensive possessions such as cameras and luggage. Thus, tourists become targets of criminals while they are in host countries. The perception of crime at the macro level has a negative impact on tourist demand in a country; countries with a high level of crime experience a reduced number of tourist arrivals. This adverse impact of crime has been affirmed by multiple studies in different countries including Jamaica, Mexico, South Africa, and Trinidad and Tobago (Lopez and Marcelo, 2019; Matakovic and Mataković, 2019; Mohammed and Sookram, 2015; Santana-Gallego and Fourie, 2020). This decline of tourist arrivals leads to a reduction in tourism revenue in the affected countries. Reviewed literature showed that the tourism industry responds differently to economic, political and financial risks (Azhar at al., 2018; Kebede, 2018; Yap and Saha, 2013), where financial and economic risk factors, such as the deprecation of the domestic currency, can encourage spending by international tourists (Ardahaey, 2011; Muzindutsi and Manaliyo, 2018). This suggests that the impact of economic and financial uncertainties on the performance of the tourism sector may differ from the effect of political risk. Additionally, if a country has a large cohort of domestic tourists, the shift to spending on domestic tourism during the time of economic, financial and political crises can sustain the industry. The implication is that tourism revenue can still grow despite times of uncertainty. This study adds to this debate by examining the short- and long-run effects of political, economic and financial risks on the performance of the South African tourism industry, focusing on the international tourist arrivals and total tourism revue. 


\section{MATERIALS AND METHODS}

This study adopted a quantitative research method with time series analysis of monthly observations to test short- and long-run relationships between tourist arrivals, tourism revenue and country risk factors for the period January 2004December 2018. The selection of this sample period was based on the availability of data. Due to the unavailability of data, the sample period for the tourism accommodation revenue analysis was adjusted to the period between January 2007 and December 2018. The number of recorded tourist arrivals in South Africa and the total revenue from tourism accommodation during the sample period was collected from Statistics South Africa (Stats SA). Total revenue from tourism accommodation comprises of seasonally adjusted total real income from hotels, guest houses and guest farms, caravan parks and camping sites, and restaurant and bar sales (Stats SA, 2019). The country's risk components are measured by South Africa's economic, financial, and political risk ratings, accessed from the International Country Risk Guide (ICRG), an investment risk company which provides economic, financial and political risk ratings of 140 countries (PRS Group, 2021). A political risk rating captures how conflict and government instability affect a particular country (Muzindutsi et al., 2021). Economic risk focuses on the possible weaknesses or strengths of a country by rating the growth factors such as inflation, GDP growth, and budget balance, whilst financial risk considers the ability of a country to settle its debt based on foreign debt and the level of liquidity. Political risk has a score of 100, while financial risk and economic risk both have scores of 50 each (PRS Group, 2018). A country with a high risk score has low country risk, whereas a country with low-risk score has high country risk.

This study utilised the Autoregressive Distributed Lag (ARDL) model to assess short- and long-run effects of country risk components on tourist arrivals and tourism revenue. The ARDL model, by Pesaran and Shin (1998) and Pesaran et al. (2001), is a relatively new but a highly favoured and valuable cointegration model. Unlike other commonly used cointegration models such as those of Engle and Granger (1987) and Johansen (1988), the ARDL model is superior in that it allows for variables integrated of order $\mathrm{I}(0)$, I(1) or a combination of the two, to be tested for cointegration. However, similar to other models, the ARDL model cannot be estimated for variables integrated of I(2) (Pesaran et al., 2001). In order to ascertain whether the variables under observation were I(2) or not, a unit root test was conducted using the Augmented Dickey Fuller (ADF) test, whose results were confirmed by the Kwiatkowski-Philips Schmidt-Shin (KPSS) stationarity test. To achieve the objective of this study, the following two ARDL equations were estimated:

$$
\begin{aligned}
\Delta L T A_{t}= & \alpha_{0}+\sum_{i=1}^{n} b_{i} \Delta L T A_{t-i} \sum_{i=0}^{n} c_{i} \Delta L E R_{t-i}+\sum_{i=0}^{n} d_{i} \Delta L F R_{t-i}+\sum_{i=0}^{n} e_{i} \Delta L P R_{t-i}+\varphi_{1} L T A_{t-1}+\varphi_{2} L E R_{t-1}+ \\
& \varphi_{3} L F R_{t-1}+\varphi_{4} L P R_{t-1}+\varepsilon_{t} \\
\Delta L T R_{t}= & \alpha_{0}+\sum_{i=1}^{n} b_{i} \Delta L T R_{t-i} \sum_{i=0}^{n} c_{i} \Delta L E R_{t-i}+\sum_{i=0}^{n} d_{i} \Delta L F R_{t-i}+\sum_{i=0}^{n} e_{i} \Delta L P R_{t-i}+\varphi_{1} L T A_{t-1}+\varphi_{2} L E R_{t-1}+ \\
& \varphi_{3} L F R_{t-1}+\varphi_{4} L P R_{t-1}+\varepsilon_{t}
\end{aligned}
$$

Where: $\Delta$ LTAt is the change in the natural log value tourist arrivals at time t, $\Delta$ LTAt is the change in the natural log of tourism revenue at time $t, \Delta$ LERt-i is the change in the natural log value of economic risk at time $t, \Delta$ LFRt-i is the change in the natural $\log$ value of financial risk at time $t, \Delta$ LPRt-i is the change in the natural log value of political risk at time $t, \alpha$, $\mathrm{b}$ and $\mathrm{c}$ are the short-run effects, while $\mathrm{i}$ and $1 \mathrm{t}$ refer to the long-run effects and the error-term, respectively. To test for the long-run relationship between the variables, the following hypothesis tests were used:

$$
\begin{aligned}
& H_{1}: \varphi_{1}=\varphi_{2}=\varphi_{3}=\varphi_{4}=0 \text { (No long-run relationship exists) } \\
& H_{2}: \varphi_{1}=\varphi_{2}=\varphi_{3}=\varphi_{4}=0 \text { (A long-run relationship exists) }
\end{aligned}
$$

This Null Hypothesis was tested against the alternative using the F-Bounds co-integration test were the F-statistic is compared to the critical values within the upper I(1) and lower bounds $\mathrm{I}(0)$. If the critical value is larger than the critical values from the upper bound, $\mathrm{HO}$ is rejected suggesting that there is a co-integrating relationship between the variables. Conversely, if the F-statistic is lower than both the upper and lower bounds, it can be concluded that there is no cointegrating relationship amongst the variables. Finally, if the F-statistic lies between the upper and lower bounds it is inconclusive whether co-integration exists or not. In the case that co-integration exists amongst the variables, the following ARDL Error Correction Model (ECM) is estimated as per Pesaran et al. (2001):

$$
\Delta L T A_{t}=\alpha_{0}+\sum_{i=1}^{k} b_{1 i} \Delta L T A_{t-i}+\sum_{i=0}^{k} c_{1} \Delta L E R_{t-i}+\sum_{i=0}^{k} d_{i} \Delta L F R_{t-i} \delta E C T_{t-1}+u_{t}
$$

Where: ECT is an error correction term, which measures the speed of adjustment back to the equilibrium in the cointegrating relationships. The same ECM was also estimated for LTR. While the this ARDL model allows for the estimation of the short and long-run relationship between the variables, its major shortfall lies in its restricting assumption that the dependent variable, tourist arrivals, responds symmetrically to the independent variables, economic, financial and political risk, thus rendering incapable of capturing possible non-linear relations between the variables (Cheah et al., 2017). Taking this into account, this study also adopted the NARDL, coined by Shin et al. (2014), to test for co-integration amongst tourist arrivals and country risk, as it is accommodating of these asymmetric short and long-run relationships amongst variables. The NARDL model was also considered to assess if there is an asymmetric relationship between tourist arrivals, tourism revenue and country risk. Following Shin et al. (2014), the estimated NARDL is as follows:

$$
\begin{aligned}
\Delta L T A_{t}= & \alpha_{0}+\sum_{i=1}^{n-1} b_{i} \Delta L T A_{t-i}+\sum_{i=0}^{n}\left(c_{1 i}^{+} \Delta L E R_{t-1}^{+}+c_{2 i}^{-} \Delta L E R_{t-i}^{-}\right)+\sum_{i=0}^{n}\left(d_{1 i}^{+} \Delta L F R_{t-i}^{+}+d_{2 i}^{-} \Delta L F R_{t-i}^{-}\right)+ \\
& \sum_{i=0}^{n}\left(e_{1 i}^{+} \Delta L P R_{t-i}^{+}+e_{2 i}^{-} \Delta L P R_{t-i}^{-}\right)+\varphi_{1}^{+} L T A_{t-i}^{+}+\varphi_{2}^{-} L T A_{t-i}^{-}+\varphi_{3}^{+} L E R_{t-i}^{+}+\varphi_{4}^{-} L E R_{t-i}^{-}+\varphi_{5}^{+} L F R_{t-i}^{+}+ \\
& \varphi_{6}^{-} L F R_{t-i}^{-}+\varphi_{7}^{+} L P R_{t-i}^{+}+\varphi_{8}^{-} L P R_{t-i}^{-}+\varepsilon_{1 t}
\end{aligned}
$$


For tourism accommodation revenue, LTA was replaced by LTR. The hypothesis tests for the NARDL model are:

$H_{0}: \varphi_{1}^{+}=\varphi_{2}^{-}=\varphi_{3}^{+}=\varphi_{4}^{-}=\varphi_{5}^{+}=\varphi_{6}^{-}=\varphi_{7}^{+}=\varphi_{8}^{-}$

$H_{0}: \varphi_{1}^{+} \neq \varphi_{2}^{-} \neq \varphi_{3}^{+} \neq \varphi_{4}^{-} \neq \varphi_{5}^{+} \neq \varphi_{6}^{-} \neq \varphi_{7}^{+} \neq \varphi_{8}^{-}$

Subsequently, the error correction model for the NARDL was specified as:

$\Delta L T A_{t}=\alpha_{0}+\sum_{i=1}^{n-1} b_{i} \Delta L T A_{t-i}+\sum_{i=0}^{n}\left(c_{1 i}^{+} \Delta L E R_{t-1}^{+}+c_{2 i}^{-} \Delta L E R_{t-i}^{-}\right)+\sum_{i=0}^{n}\left(d_{1 i}^{+} \Delta L F R_{t-i}^{+}+d_{2 i}^{-} \Delta L F R_{t-i}^{-}\right)+$

$\sum_{i=0}^{n}\left(e_{1 i}^{+} \Delta L P R_{t-i}^{+}+e_{2 i}^{-} \Delta L P R_{t-i}^{-}\right)+\delta E C T+\varepsilon_{1 t}$

The most reliable ARDL and NARDL model was chosen according to the Akaike Information Criteria due to the relatively small sample size. Both the ARDL and the NARDL models were tested for heteroscedasticity, serial correlation and parameter stability to ensure the reliability of the results.

\section{RESULTS AND CONCLUSIONS}

1. Descriptive Statistics

Table 1 displays the descriptive statistics of the series. All variables were converted into logarithms for the investigation of the relationship of the elasticities of the variables. From Table 1, it is evident that the standard deviations of all variables are smaller than their means, indicating that the variables did not deviate from their mean values over the period. Moreover, the LER, LFR and LPR seems to be less volatile than the LTA and LTR, with LTR bring the most volatile. With a kurtosis value of three, and a skewness value very close to one, LTA exhibits a normal distribution. This is confirmed by its Jarque-Bera statistic, were it shows a probability value higher than all levels of significance which leads to fail to reject the null hypothesis of normality. Similarly, the LER which has a kurtosis close to 3 and a Jarque-Brea probability value of 0.297555. The null hypothesis is not rejected, suggesting that LER is normally distributed. However, LTR, LFR and LPR exhibit a platykurtic distribution as shown by their kurtoses which are lower than three and Jarque-Bera probability values which are lower than $5 \%$ level of significance.

Table 2. ADF and KPSS results

(with a constant) Source: Authors computation

Table 1. Descriptive statistics (Source: Authors computation)

\begin{tabular}{|l|l|l|l|l|l|}
\hline & LTA & LTR & LER & LFR & LPR \\
\hline Mean & 13.50330 & 7.991381 & 3.535970 & 3.629044 & 4.197527 \\
\hline Median & 13.50583 & 7.992528 & 3.526361 & 3.637586 & 4.197202 \\
\hline Maximum & 13.91440 & 8.320594 & 3.650658 & 3.737670 & 4.269697 \\
\hline Minimum & 13.03007 & 7.489356 & 3.367296 & 3.449988 & 4.119037 \\
\hline Std. Dev & 0.157267 & 0.236041 & 0.064660 & 0.062897 & 0.040193 \\
\hline Skewness & -0.322607 & -0.194812 & 0.180909 & -0.614342 & -0.103964 \\
\hline Kurtosis & 3.032754 & 1.832214 & 2.561445 & 2.571549 & 2.056516 \\
\hline Jarque Bera & 3.130306 & 9.093190 & 2.424315 & 12.69925 & 7.000480 \\
\hline Probability & 0.209056 & 0.010603 & 0.297555 & 0.001747 & 0.030190 \\
\hline Sum & 2430.594 & 1150.759 & 636.4746 & 653.2279 & 755.5549 \\
\hline Sum Sq. Dev. & 4.427202 & 7.967317 & 0.748373 & 0.708128 & 0.289172 \\
\hline
\end{tabular}

Table 3. F-Bounds Co-integration test results and

long-run equations (Source: Authors computation)

\begin{tabular}{|c|c|c|c|c|c|}
\hline Model & \multicolumn{2}{|l|}{ F-statistic } & $\begin{array}{l}\text { Lower } \\
\text { Bound }\end{array}$ & $\begin{array}{l}\text { Upper } \\
\text { Bound }\end{array}$ & Conclusion \\
\hline \multirow{2}{*}{$\begin{array}{l}\text { ARDL } \\
\text { (TA) }\end{array}$} & 8.299628 & $\begin{array}{l}5 \% \\
1 \%\end{array}$ & $\begin{array}{l}3.23 \\
4.29\end{array}$ & $\begin{array}{l}4.35 \\
5.61\end{array}$ & Co-integrated \\
\hline & \multicolumn{5}{|c|}{$\begin{array}{l}\text { Long-run equation: } \\
\text { LTA }=0.8006 \mathrm{LER}-0.7418 \mathrm{LFR}-2.1252 \mathrm{LPR}\end{array}$} \\
\hline \multirow{2}{*}{$\begin{array}{l}\text { ARDL } \\
\text { (TR) }\end{array}$} & 5.144848 & $\begin{array}{l}5 \% \\
1 \%\end{array}$ & $\begin{array}{l}4.01 \\
5.17\end{array}$ & $\begin{array}{l}5.07 \\
6.36\end{array}$ & Co-integrated \\
\hline & \multicolumn{5}{|c|}{$\begin{array}{l}\text { Long-run equation: } \\
\text { LTR }=0.3047 \text { LER }+0.0157 \text { LFR - 1.3641LPR }\end{array}$} \\
\hline \multirow[b]{2}{*}{$\begin{array}{l}\text { NARD } \\
\text { L(TA) }\end{array}$} & 5.351754 & $\begin{array}{l}5 \% \\
1 \%\end{array}$ & $\begin{array}{l}2.27 \\
2.88\end{array}$ & $\begin{array}{l}3.28 \\
3.99\end{array}$ & Co-integrated \\
\hline & \multicolumn{5}{|c|}{ 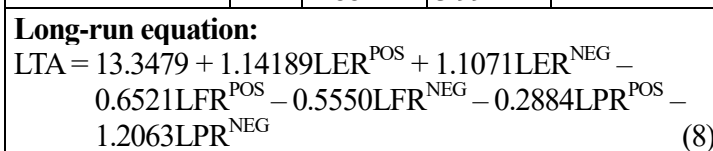 } \\
\hline \multirow[b]{2}{*}{$\begin{array}{l}\text { NARD } \\
\text { L(TR) }\end{array}$} & 4.907425 & $\begin{array}{l}5 \% \\
1 \%\end{array}$ & $\begin{array}{l}2.87 \\
3.6\end{array}$ & $\begin{array}{l}4.0 \\
4.9\end{array}$ & Co-integrated \\
\hline & \multicolumn{5}{|c|}{ 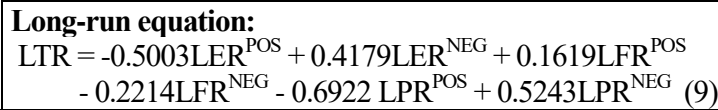 } \\
\hline
\end{tabular}

\begin{tabular}{|c|c|c|c|c|c|}
\hline & \multicolumn{2}{|c|}{ Levels } & \multicolumn{2}{|c|}{ First difference } & \multirow{2}{*}{$\begin{array}{c}\text { Integration } \\
\text { Order }\end{array}$} \\
\hline Series & $\begin{array}{l}\text { ADF } \\
\text { t-stat }\end{array}$ & $\begin{array}{l}\text { KPSS } \\
\text { LM-stat }\end{array}$ & $\begin{array}{l}\mathrm{ADF} \\
\text { t-stat }\end{array}$ & $\begin{array}{l}\text { KPSS } \\
\text { LM-stat }\end{array}$ & \\
\hline LTA & -2.463083 & \begin{tabular}{|l|}
1.052674 \\
\end{tabular} & -3.165259 & 0.006653 & $\mathbf{I}(\mathbf{1})$ \\
\hline LTR & -2.439760 & 0.577377 & -11.28061 & 0.121165 & I(1) \\
\hline LER & -2.007266 & 0.968115 & -8.084116 & 0.063447 & I(1) \\
\hline LFR & -3.028687 & 1.009163 & ------ & ------- & $\mathbf{I}(\mathbf{0})$ \\
\hline LPR & -1.540942 & 1.493237 & -8.417106 & \begin{tabular}{|l|}
0.0735999 \\
\end{tabular} & I(1) \\
\hline
\end{tabular}

Table 4. Error Correction Model (Source: Authors computation)

\begin{tabular}{|c|c|c|c|}
\hline Model & Variables & Coefficients & Probability \\
\hline \multirow{6}{*}{ ARDL(TA) } & $\mathrm{C}$ & 10.21102 & 0.0000 \\
\hline & $\mathrm{D}(\mathrm{LTA}(-1))$ & -0.134737 & 0.0747 \\
\hline & $\mathrm{D}$ (LER) & 0.687220 & 0.1127 \\
\hline & $\overline{D(L F R)}$ & -0.565996 & 0.0524 \\
\hline & D(LPR) & -1.241768 & 0.1878 \\
\hline & CointEq(-1) & -0.458074 & 0.0000 \\
\hline \multicolumn{4}{|l|}{ ARDL(TR) } \\
\hline & $\mathrm{C}$ & 3.938489 & 0.0000 \\
\hline & @-TREND & 0.001464 & 0.0001 \\
\hline & $\overline{\mathrm{D}(\mathrm{LTR}(-1))}$ & -0.077048 & 0.3679 \\
\hline & D(LER) & 0.052117 & 0.8132 \\
\hline & $\mathrm{D}(\operatorname{LER}(-1))$ & -0.248467 & 0.2583 \\
\hline & $\mathrm{D}(\mathrm{LFR})$ & -0.166880 & 0.2710 \\
\hline & $\mathrm{D}(\mathrm{LFR}(-1))$ & 0.042031 & 0.7801 \\
\hline & $\mathrm{D}(\mathrm{LPR})$ & 0.022887 & 0.9623 \\
\hline & $\mathrm{D}(\mathrm{LPR}(-1))$ & 1.069953 & 0.0284 \\
\hline & CointEq(-1) & -0.321256 & 0.0000 \\
\hline \multicolumn{4}{|l|}{ NARDL TA } \\
\hline & $\mathrm{D}(\mathrm{LTA}(-1))$ & -0.089479 & 0.2343 \\
\hline & D(LER POS) & 0.810270 & 0.2159 \\
\hline & D(LER_NEG) & 0.731378 & 0.2394 \\
\hline & D(LFR_POS) & -0.256517 & 0.5558 \\
\hline & D(LFR_NEG) & -0.755430 & 0.0926 \\
\hline & D(LPR POS) & -0.192134 & 0.8768 \\
\hline & D(LPR_NEG) & -2.322271 & 0.1090 \\
\hline & CointEq(-1) & -0.559308 & 0.0000 \\
\hline \multicolumn{4}{|l|}{ NARDL TR } \\
\hline & $\mathrm{C}$ & 3.084967 & 0.0000 \\
\hline & @TREND & 0.002830 & 0.0000 \\
\hline & CointEq(-1) & -0.404703 & 0.0000 \\
\hline
\end{tabular}




\section{Unit root test results}

The ARDL models are not reliable if any of the variables are I(2); therefore, to ensure this was not the case, the ADF unit root and KPSS stationarity tests were conducted. These two tests are the most frequently used for testing the order of integration of a variable and their power together lies within their distinct null hypotheses (Moravej, 2016). The results of the tests revealed that LTA, LTA, LER, and LPR are integrated of order 1, indicating that they are stationary only at first difference, whilst LFR is integrated of order zero meaning that it remains stationary at levels. Firstly, the results of the ADF and KPSS tests in Table 2 shows that the variables are integrated of different orders, which supports the use of the ARDL models. Secondly, the results showed that none of the variables are I(2), and thus allowing the use of the ARDL and NARDL models.

\section{Analysis of the long-run relationships}

Based on the AIC, the best models were ARDL $(2,1,1,1)$ for TA, ARDL(TR) [2, 2, 2, 2], NARDL(TA) [2,1,1,1,1,1,1], and (NARDL(TR) $[1,0,0,0,0,0,0]$ where the values within the parentheses represent the lag number of each variable used in the model. The results of the ARDL and NARDL F-Bounds test and long-run equations are summarised in Table 3.

Both F-statistics of the ARDL(TA) and the 2 NARDL models exceed the lower and upper bound critical values at $1 \%$ level of significance, whilst ARDL(TR) exceeds 5\% upper and lower bound critical values. This, allows for the rejection of their respective null hypotheses of no co-integrating relationship between the variables. These findings suggest that there is a long-run relationship between tourist arrivals and country risk components as well as tourism revenue and country risk components. The null hypothesis of the NARDL stating that the positive and negative impact of the economic, financial and political risk having the same impact on tourist arrivals is also rejected. This suggests that the observed long-run relationships between tourist arrivals and country risk measures along with tourist revenue and country risk measures are asymmetric. These asymmetric relationships were further solidified by the Akaike Information Criteria results, which favoured NARDL models.

Equations 6, 7, 8, and 9 express the long-run equations of the ARDL(TA), ARDL(TR), NARDL(TA) and NARDL(TR) respectively. Given the confirmation of asymmetric long-run relationships between tourist arrivals and the country risk measures, NARDL long-run equations ( 8 and 9) are discussed. Equation 8 reveals that positive and negative changes in economic risk rating score have similar long-run positive effects on tourist arrivals. Considering that a high country risk rating value indicates low overall country risk (Howell, 2012), a decrease in the level economic risk (implying increase in economic risk index score) increases tourist arrivals in long-run. This implies that economic stability has a positive long-run implication on tourist arrivals. An increase in the level of an economic risk component such as inflation, cost of living in a destination country decreases demand for tourism in the country (Mihalič, 2002; Ardahaey, 2011). This highlights the significant role that economic risk plays in South Africa's tourist arrivals. The implication is that economic stability in South Africa is crucial for the future of the tourism industry. Equation 8 further shows that the long-run effects of political and financial risks on tourist arrivals are asymmetric, as negative and positive changes in these risks have different effects on tourist arrivals. The opposite signs of the coefficients imply that tourist arrivals increase or decrease with positive or negative changes in political and financial risk scores, indicating that there is a positive long-run relationship between financial and political risk scores and tourist arrivals. This means that a decline in the level of financial and political risks leads to an increase in tourist arrivals. It should be noted that the impacts of both these risks are asymmetric. With regard to financial risk, its positive impact on tourist arrivals is greater than its negative impact. This indicates that the number of tourist arrivals that visit South Africa are more sensitive to increasing financial risk. It is held that an increase in financial risk causes depreciation of a local currency makes travelling more cost effective for international tourists; resulting in increased tourist arrivals (Howell, 2012). Conversely, tourist arrivals in South Africa are more sensitive to an increase in the level of political risk compared with a decrease in the level of the risk. The policy implication of this result is that increased government stability and absence of internal and external conflicts in South Africa may benefit the country's tourism industry in the long-run.

For the tourism revenue on the other hand, equation 9 indicated that the type of relationship that tourism revenue has with the country risk components, depends on the direction of the impact of each component. For example, tourism revenue responds negatively to positive changes in economic risk index score and positively to negative changes in economic risk index score. These results suggest that an increase in the level of economic risk (implying a decrease in economic risk index score) have a negative impact on tourism revenue in the long-run. Similarly, a decline in economic risk index score (implying increase in an economic risk level) was associated with increases in the tourism revenue in the long-run, tourism revenue had a converse relationship with financial risk. A decline in the level of financial risk leads to an increase in tourism revenue. Results showed that a declining financial risk level increases tourism revenue. Finally, a positive relationship was observed between political risk and tourism revenue. A decline in political risk results in decreases tourism revenue whilst a decline in political risk score leads to increases in tourism revenue in the long-run. These results collaborate the findings from previous studies (Baker, 2014; Kebede, 2018; Muzindutsi and Manaliyo, 2016; 2018; Santana-Gallego et al. 2016), which established that the prevalence of country risk factors has a negative long-run effect on tourism sector.

It is noted that LPR had the highest long-run effect on the ARDL(TA), ARDL(TR), as well as the NARDL(TA) and NARDL(TR). This emphasises the key role of political risk in decision making by tourists to visit South Africa, which also affects the revenue generated by the tourism industry in the country. The results from the revenue equation suggest that the tourism revenue benefits from economic and political uncertainties. These findings are unexpected and are different from those for the international tourist arrivals, which are contrary to the previous findings (Chingarande, 2014; Ingram et al., 2013; Ivanov et al., 2016; Kebede, 2018) that linked to political instability to both tourist arrivals and tourism revenue. This suggests the decline in international arrivals due to political and economic uncertainties may not necessarily affect the tourism revenue in the long-run. The plausible explanation of this relationship is reliance on local tourists who would consider 
the local tourism destination, instead of international destination, during difficult times (Muzindutsi and Manaliyo, 2016). Such a shift to the local market possibly offsets the revenue lost from international tourists. This emphasises the role of local tourists in sustaining the tourism industry during political and economic turmoil. The long-run results further showed that financial uncertainty has a detrimental effect on total tourism revenue as well as the international tourist arrivals. This suggested that financial difficulties create an unfavourable environment for the South African tourism industry as it compromises the spending capacity of local tourists. This is expected as financial risk has been found to have a negative impact on financial marks (Nhlapho and Muzindutsi, 2020) compromising consumers borrowing and spending ability. This showed that a stable financial environment is essential in ensuring the sustainability of the South African tourism industry.

\section{Analysis of short-run relationships}

Provided those co-integrating relationships, error correction models were proposed with the results summarised in Table 4. These results indicated short-run dynamics between the variables a well as the models' speed of adjustment back to equilibrium. The t-Bounds statistics showed that the error correction terms (ECT) of all of the models were significant as the $\mathrm{t}$-stat is greater than the upper bound $\mathrm{t}$-values at the $5 \%$ level of significance. The combination of a negative and significant ECT is the desired outcome for a short-run relationship to exist. This conveyed that for any disequilibrium, there is a correction back to long-run equilibrium (Brooks, 2014). The ECT for the ARDL(TA) and ARDL(TR) model indicates that about 45.8 and $32.13 \%$ of any deviation from equilibrium is corrected respectively every month. Similarly, the ECT for the NARDL(TA) and NARDL(TR) suggested that 55.93 and 40,47\% of any disequilibrium respectively, is corrected monthly. This showed that the speed of adjustment for the NARDL is significantly larger than its counterparts. The results showed that only negative impacts of financial risk have a significant short-run effect on tourist arrivals. This finding highlights the significance of policy makers understanding that the components of this risk have a major impact on the tourist arrivals. Managing financial risk effectively will simulate the tourism industry.

The discovery of long- and short-run relationships between tourist arrivals and country risk as well as tourism revenue and country risk is consistent with the findings of Muzindutsi and Manaliyo (2016), Perles-Ribes et al. (2016) and Ghosh (2019). The current findings magnify the impact of country risk shock on tourism industry. The tourism industry, as one of the South Africa's largest employers and one of its major sources of revenue is hamstrung by economic, financial and political shocks. There is a need to understand and manage these country risk components. Although the current findings showed that political, economic and financial risks affect the tourism sector, political risk has the highest effect on the sector. In the context, political risk affects the tourism industry in South Africa severely in comparison with economic and financial risks. Creating a stable political environment is essential in ensuring stable growth of the industry. Additionally, a stable financial environment is indispensable for domestic tourists who sustain the tourism revenue during difficult times. The role of domestic tourists in ensuring the survival of the industry was observed during the current period of COVID-19 pandemic.

\section{Diagnostic tests}

Before estimating the F-Bounds test on both models, residual diagnostic and stability tests were conducted. Table 5 displays the results of the Breush-Godfrey serial correlation tests as well as white heteroscedasticity tests. It is evident from the results that the residuals of all models are homoscedastic and not serially correlated at $5 \%$ level of significance. The CUSUM stability test results proved that all the parameters of both models were stable since the CUSUM and CUSUMQ graph stayed within the $5 \%$ boundaries during the sample period. These results showed that the estimated models did not violate any econometric assumptions, confirming the trustworthiness of the findings of this study.

Table 5. Residual Diagnostic tests Source: Authors computation

\begin{tabular}{|c|c|c|c|}
\hline Model & Serial Correlation test (F-stat. p-values) & White Heteroscedasticity test (F-stat. p-values) & CUSUM and CUSUMQ \\
\hline ARDL(TA) & P values 0.076 & P values 0.0646 & All models are stable at \\
\hline ARDL(TR) & P values 0.0822 & P values 0.0716 & the 5\% level of $\mathrm{s}$ \\
\hline NARDL (TA) & P values 0.1671 & P values 0.5535 & \\
\hline NARDL (TR) & P values 0.153 & P values 0.5413 & \\
\hline
\end{tabular}

\section{CONCLUSIONS}

Tourism in some countries, including South Africa, is one of the major contributors to their economy. The contribution of tourism to a country's economy is determined by numerous factors, which influence tourism activities and tourist arrivals. Some of these factors include economic, financial and political risks. Tourism reacts adversely to any changes in economic, financial and political risks because these risks inhibit the inflow of tourists to countries, leading to reduced tourism revenue. Countries with increasing economic risk, financial risk or political risk experience a decline in both tourist arrivals and tourism revenue. The findings of this paper indicate that all country risk components (economic, financial and political risks) influence the South African tourist sector but these components affect tourist arrival and tourism revenue asymmetrically. Political risk has the highest effect on the tourism industry compare with economic and financial risks.

Tourist arrivals in South Africa respond positively to any changes in financial and political risks irrespective of whether the change is an increase or decrease. This means that foreign tourists travelling to South Africa are not deterred from visiting the country by increase or declines in financial risk or political risk. With respect of financial risk, South Africa receives more tourists when this risk increases than when the level of the risk decreases. An increasing level of political risk on the other hand, attracts more tourist arrivals in comparison with tourist arrivals when the level of political risk falls. Similar to financial and political risk, tourist arrivals in South Africa seem to not be influenced by changes in economic 
risk. The number of tourist arrivals falls regardless of whether the level of economic risk goes up or goes down. Unlike tourist arrivals, tourism revenue responds positively to any changes in economic risk, implying that South African tourism revenue benefits from domestic tourists, during the time of economic uncertainty.

This study established that both international tourist arrivals and tourism revenue are threatened by financial shocks indicting that an unconducive financial environment has long-term negative implication on the South African tourism industry. Our study highlighted the vulnerability of the tourism industry to country risk shocks which has been aggravated by the severe effect of the COVID-19 pandemic on the tourism industry worldwide. South Africa therefore, has to implement friendly economic, financial and political policies. This study, however, used data of international tourism and total revenue. Perhaps separating revenues from domestic and international tourism can shed more light on the topic. Future studies may investigate the impact of country risk on domestic tourism revenue in relation to the international tourism revenue.

\section{REFERENCES}

Al-Shorman, A., Rawashdih, A., Makhadmih, A., Oudat, A., \& Darabsih, F. (2016). Middle Eastern political instability and Jordan's tourism. Journal of Tourism Research \& Hospitality, 5(1), 1-5. https://doi.org/10.4172/2324-8807.1000155

Ardahaey, F.T. (2011). Economic impacts of tourism industry. International Journal of Business and Management, 6(8), $206-215$. https://doi.org/10.5539/ijbm.v6n8p206

Azhar, G., Kuncoro, H., \& Sebayang, K.D.A. (2018). The nexus of exchange rate on tourist arrivals: the case of in Indonesia. South East Asia Journal of Contemporary Business, Economics and Law, 15(5), 70-81. http://seajbel.com/wp-content/uploads/2018/05/K14_7.pdf

Baker, D.M. (2014). The effects of terrorism on the travel and tourism industry. International Journal of Religious Tourism and Pilgrimage, 2(1), 58-64. https://doi.org/https://doi.org/10.21427/D7VX3D

Baker, D., \& Stockton, S. (2014). Tourism and crime in America: a preliminary assessment of the relationship between the number of tourists and crime, two major American tourist cities. International Journal of Safety and Security in Tourism, 5, 1-25. https://dialnet.unirioja.es/servlet/articulo?codigo $=4698968$

Basu, K., \& Marg, V.S. (2013). Impact of political instability and terrorism in the tourism industry of three Middle-East countries: an econometric exploration. http://www.ijbts-journal.com/images/main_1366796758/0002-Kaushik.pdf

Biagi, B., Brandono, M.G., \& Detotto, C. (2012). The effect of tourism on tourism in Italy: a dynamic panel approach. Economics: The Open-Access, Open-Assessment E-journal, 6, 2012-25. http://dx.doi.org/10.5018/economics-ejournal.ja.2012-25

Brooks, C. (2014). Introductory econometrics for finance, Cambridge University Press, Cambridge, The United Kingdom.

Brown, D.O. (2000). Political risk and other barriers to tourism promotion in Africa: perceptions of US-based travel intermediaries. Journal of Vacation Marketing, 6(3), 197-210. https://doi.org/10.1177/135676670000600301

Çertinsoz, B.C., \& Age, Z. (2013). Impact of perceived risks on tourists' revisit intentions. Anatolia: An International Journal of Tourism and Hospitality Research, 24(2), 173-187. https://doi.org/10.1080/13032917.2012.743921

Cheah, S.P., Yiew, T.H., \& Ng, C.F. (2017). A nonlinear ARDL analysis on the relation between stock price and exchange rate in Malaysia. Economics Bulletin, 37(1), 336-346.

Chingarande, A. (2014). Does political instability affect tourism: a case of Egypt. International Journal of Social Relevance \& Concern, 2(6), 1-4.

Dastgerdi, H.G., Yusof, Z.B., \& Shahbaz, M. (2018). Nexus between economic sanctions and inflation: a case study in Iran. Applied Economics, 50(49), 5316-5334. https://doi.org/10.1080/00036846.2018.1486988

Dolgos, G. (2019). Cuba's tourism crisis - a result of the US sanctions. Tourism Review. https://www.tourism-review.com/cubareported-a-tourism-crisis-news 11282

Ekine, S. (2018). Corruption and tourism: evidence from democracies and non-democracies. Issues in Political Economy, 27(1), 47-59.

Engle, R.F., \& Granger, C.W.J. (1987). Cointegration and error correction: representation, estimation, and testing. Econometrica, 55(1), 251-276. https://doi.org/10.2307/1913236

Everhart, S.S., Martinez-Vazquez, J., Martinez-Varquez, J., \& McNab, R.M. (2003). Corruption, investment, and growth in developing countries. Annual Conference on Taxation and Minutes of the Annual Meeting of the National Tax Association, 96, 84-90. https://www.jstor.org/stable/41954395

Fan, W., \& Luo, W.D.J. (2018). The causes of financial in enterprises and its precaution. Global Finance Review, 1(1), 1521. http://dx.doi.org/10.24294/gfr.v1i1.260

Farahani, B.M., \& Shabani, M. (2014). The impact of sanctions on Iran's tourism. International Journal of Resistive Economics, 2(1), 1-12.

Ferreira, F.A., Castro, C., \& Carvalho, V. (2019). Tourism, terrorism, perceived risk and media. AIP Conference Proceedings, 2116 (1). https://doi.org/10.1063/1.5114095

Ghosh, S. (2019). Uncertainty, economic growth its impact on tourism, some country experiences. Asia Pacific Journal of Tourism Research, 24(1), 83-107. https://doi.org/10.1080/10941665.2018.1542324

Howell, L.D. (2012). International country risk guide methodology. East Syracuse, NY: PRS Group. https://www.prsgroup.com/wpcontent/uploads/2012/11/icrgmethodology.pdf

Ingram, H., Tabari, S., \& Watthanakhomprathip, W. (2013). The impact of political instability on tourism: case of Thailand. Worldwide Hospitality and Tourism Themes, 5(1), 92-103. https://doi.org/10.1108/17554211311292475

Ito, H. \& Lee, D. (2005). Comparing the impact of the September 11th terrorist attacks on international airline demand. The International Journal of Economics of Business, 12(2), 225-249. https://doi.org/10.1080/13571510500127931

Ivanov, S., Gavrilina, M., Webster, C., \& Ralko, V. (2017). Impacts of political instability on the tourism industry in Ukraine. Journal of Policy Research in Tourism, Leisure and Events, 9(1), 100-127. https://doi.org/10.1080/19407963.2016.1209677

Johansen, S. (1988). Statistical Analysis of Cointegration Vectors. Journal of Economic Dynamics and Control, 12(2-3), 231-254. https://doi.org/10.1016/0165-1889(88)90041-3

Kandil, M. (2015). The adverse effect of real exchange rate variability in Latin America and the Caribbean. Journal of Applied Economics, 18(1), 99-120. https://doi.org/10.1016/S1514-0326(15)30005-2

Kandir, S.Y., Karadeniz, E., \& Erismis, A. (2015). The exchange rate of Turkish tourism firms. Journal of Hospitality Financial Management, 23, 63-71. https://doi.org/10.1080/10913211.2015.1038169

Kebede, N.S. (2018). The fate of tourism during and in the aftermath of political instability: Ethiopia tourism in focus. Journal of Tourism \& Hospitality, 7(1), 1-7. https://doi.org/10.4172/2167-0269.1000337

Lopez, F.S., \& Marcelo, J.N.C. (2019). Kidnapping as a long-term factor for cruise tourism: evidence from Mexico. https://doi.org/ 10.13043/DYS.83.5

Matakovic, H., \& Mataković, I.C. (2019). The impact of crime on security in tourism. Security and Defence Quarterly 27(5), 1-20. https://doi.org/10.35467/sdq/115539 
Mihalič, T. (2002). Tourism and development: concepts and issues. In Tourism and Economic Development Issues (pp 81-111). Channel View Publications, Clevedon, the United Kingdom.

Mohammed, A.M., \& Sookram, S. (2015). The impact of crime on tourist arrivals - a comparative analysis of Jamaica and Trinidad and Tobago. Social and Economic Studies, 64(2), 153-176. https://www.jstor.org/stable/26379938

Moravej, M. (2016). Investigating climate change using AK stationarity test in the Lake Urmia basin. International Journal of Hydrology Science and Technology, 6(4), 382-407. https://doi.org/10.1504/IJHST.2016.079349

Muzindutsi, P.F., Jamile, S., Zibani, N., \& Obalade, A.A. (2021). The effects of political, economic and financial components of country risk on housing prices in South Africa. International Journal of Housing Markets and Analysis, 14(3), 523-537. https://doi.org/10.1108/IJHMA-05-2020-0060

Muzindutsi, P.F., \& Manaliyo, J.C. (2018). Econometric analysis of real exchange rate shocks and real growth of the tourism sector in South Africa. International Journal of Monetary Economics and Finance, 11(3), 205-214. https://doi.org/10.1504/IJMEF.2018.093787

Muzindutsi, P.F., \& Manaliyo, J.C. (2016). Effect of political risk shocks on tourism revenue in South Africa: Time series analysis. International Journal of Business and Management studies, 8(2), 169-186.

Neumayer, E. (2004). The impact of political violence on tourism-dynamic econometric estimation in a cross-national panel. Journal of Conflict Resolution, 48(2), 259-281. https://doi.org/10.1177/0022002703262358

Nhlapho, R., \& Muzindutsi, P.F. (2020). The impact of disaggregated country risk on the South African equity and bond market. International Journal of Economics and Finance Studies, 12(1), 189-203. https://doi.org/10.34109/ijefs.202012112

Nugraha, A., Hamin, H., \& Elliot, G. (2016). Tourism destination decisions: the impact of risk aversion and prior experience. Asia Pacific Journal of Tourism Research, 21(12), 1274-1284. https://doi.org/10.1080/10941665.2016.1141225

Oláh, J., Kovács, S., Virglerova, Z., Lakner, Z., Kovacova, M., \& Popp, J. (2019). Analysis and Comparison of Economic and Financial Risk Sources in SMEs of the Visegrad Group and Serbia. Sustainability, 11(1853), 1-19. https://doi.org/10.3390/su11071853

Perles-Ribes, J.F., Ramón-Rodríguez, A.B., Sevilla-Jiménez, M., \& Rubia, A. (2016). The effects of economic crises on tourism success: An integrated model. Tourism Economics, 22(2), 417-447. https://doi.org/10.5367/te.2014.0428

Pesaran, M.H., \& Shin, Y. (1998). An autoregressive distributed lag modelling approach to cointegration analysis. In Econometrics and Economic Theory in the 20th Century: The Ragnar Frisch Centennial Symposium (pp. 371-413). Cambridge University Press, Cambridge, UK. https://doi.org/10.1017/CCOL521633230.011

Pesaran, M.H., Shin, Y., \& Smith, R.J. (2001). Bounds testing approaches to the analysis of level relationships. Journal of Applied Econometrics, 16(1), 289-326. https://doi.org/10.1002/jae.616

Platon, V., Frone, S., \& Constantinescu, A. (2014). Financial and economic risks to public projects. Procedia Economics and Finance, 8, 204 - 210. https://doi.org/10.1016/S2212-5671(14)00082-3

Poprawe, M. (2015). A panel data analysis of the effect of corruption on tourism. Applied Economics, 47(23), $2399-2412$. https://doi.org/10.1080/00036846.2015.1005874

Quadri, D., \& Zheng, T. (2011). A revisit to the impact of exchange rates on tourism demand: the case of Italy. Journal of Hospitality Financial Management, 18(2), 47-60. https://doi.org/10.1080/10913211.2010.10653894

Santana-Gallego, M., \& Fourie, J. (2020). Tourism falls apart: how insecurity affects African tourism. Tourism Economics, https://doi.org/10.1177/1354816620978128

Santana-Gallego, M., Rosselló-Nadal, J., \& Fourie, J. (2016). The effects of terrorism, crime and corruption on tourism. Working Papers 595, Economic Research Southern Africa. https://www.aecit.org/files/congress/19/papers/150.pdf.

Seetanah, B., Juwaheer, T.D., Lamport, M.J., Rojid, S., Sannassee, R.V., \& Subadar, A.U. (2011). Does infrastructure matter in tourism development? University of Mauritius Research Journal, 17, 89-108. https://doi.org/10.4314/umrj.v17i1.70731

Shin, Y., Yu, B., \& Greenwood-Nimmo, M. (2014). Modelling asymmetric cointegration and dynamic multiplier in a nonlinear ARDL framework. In Festschrift in Honor of Peter Schmidt: Econometric Methods and Applications (pp. 281-314), Springer, New York, the United States of America. https://doi.org/10.1007/978-1-4899-8008-3_9

Yap, G., \& Saha, S. (2013). Do political instability, terrorism, and corruption have deterring effects on tourism development even in the presence of UNESCO heritage? A cross-country panel estimate. Tourism Analysis, 18, 587-599. https://doi.org/ 10.3727/108354213X13782245307911

Thabani, N. (2019). The curse is real in Zimbabwe: economic sanctions must go! MPRA Paper 96911, University Library of Munich, Germany. https://mpra.ub.uni-muenchen.de/96911/1/MPRA_paper_96911.pdf

Tung, L.T. (2019). Does exchange rate affect the foreign tourist arrivals? Evidence in an emerging tourist market. Management Science Letters, 9, 1141-1152. https://doi.org/10.5267/j.msl.2019.5.001

Vojtko, V., Stumpf, P., Kovacic, M., \& Janecek, P. (2018). Better understanding of exchange rate in destination marketing: cases of the Czech Republic and Croatia. Tourism: An International Interdisciplinary Journal, 66(4), 379-395. https://doi.org/10.37741/t

*** PRS Group. (2021). The International country risk guide (ICRG). https://prsgroup.com/explore-our-products/international-country-risk-guide/

*** PRS Group. (2018). International country risk guide methodology. https://www.prsgroup.com/wp-content/uploads/2018/01/ icrgmethodology.pdf

*** Statistics South Africa (2019). Time series data. Retrieved from http://www.statssa.gov.za/?page_id=1847.

*** United Nations World Tourism Organisation. (2019a). International tourism highlights 2019 edition. https://www.eunwto.org/doi/pdf/10.18111/9789284421152

*** United Nations World Tourism Organisation. (2019b). 2018: international tourist arrivals reach two years ahead of forecasts. World Tourism Barometer, 17(1), 1-13.

*** United Nations World Tourism Organisation. (2015). UNWTO tourism highlights 2015 edition. https://www.eunwto.org/doi/pdf/10.18111/9789284416899

*** United Nations World Tourism Organisation. (2010). UNWTO tourism highlights 2010 edition. https://www.eunwto.org/doi/pdf/10.18111/9789284413720

*** United Nations World Tourism Organisation \& International Labour Organisation. (2013). Economic crisis, international tourism demand decline and its impact on the poor. https://www.ilo.org/wcmsp5/groups/public/---ed_dialogue/---sector/documents /publication/wcms_214576.pdf

*** World Travel and Tourism Council. (2020). Global economic impact and trends 2020. https://wttc.org/Portals/0/Documents/ Reports/2020/Global\%20Economic\%20Impact\%20Trends\%202020.pdf?ver=2021-02-25-183118-360 